\title{
補綴的発音補助装置（スピーチエイド）の適応と効果
}

道健一

要 約：口腔・咽頭部の器質的, 機能的障害に起因する言語障害の治療には外科的治療ある いは機能訓練のほかに, 歯科的な技術を応用した補経的治療が適用される。一般に, 器質的な 異常に対しては第一に外科的治療が選択される. 器質的な異常でも外科的に正常な機能が得ら れない場合，あるいは，手術が適用となりにくい場合，および機能的な異常による場合には補 経的治療と機能訓練の適用が検討される．特に，全身状態が不良な患者，あるいは外科的治療 をすでに行って言語障害が残存している患者では補綴的治療の適応を第一選択に考えて治療方 針を立てるべきである。

補経的治療の方法および補綴的発音補助装置は補綴される部位, 機能によって分類される. その内の主な装置 (上顎顎義歯, バルブ型スピーチエイド, 軟口蓋挙上装置, 舌接触補助床) の適応と効果について述べた.

索引用語：補経的発音補助装置, 鼻咽腔閉鎖機能不全, 構音障害, 口腔癌, 運動障害性構音 障害

\section{Application of Prosthetic Speech Appliances and their Effectiveness}

\section{Kenichi Michi}

\begin{abstract}
In addition to surgical methods and speech training, prosthetic appliances applying technical knowledge from dentistry are used to treat speech disorders caused by organic or functional impairment in the oral and pharyngeal regions. Generally, surgical methods are applied for organic diseases as the first choice. Prosthetic and functional training procedures are applied to organic diseases in which adequate function is not obtainable through surgical procedures or surgical procedures are not suitable. Prosthetic procedures should be considered as the first choice in treatment especially of physically compromised patients or patients who continue to suffer from speech disorders after surgery.

Prosthetic procedures or appliances are classified according to the site and function to be compensated. Applications of prosthetic speech appliances in common usages and their effectiveness are discussed.
\end{abstract}

昭和大学名誉教授 ${ }^{1)}:$ 个 145-8515 東京都大田区北千束 2-1-1

東京医科歯科大学医歯学教育システム開発センタ ${ }^{21}$ : ₹ 113-8549 文京区湯島 1-5-45

${ }^{1)}$ Professor Emeritus, Showa University : 2-1-1, Kitasenzoku, Ohta-ku, Tokyo 145-8515, Japan

${ }^{2)}$ Center for Education Research in Medicine and Dentistry, Tokyo Medical and Dental University : 5-45, Yushima 1-chome,

Bunkyo-ku, Tokyo 113-8549, Japan

原稿受理：2002 年 5 月 24 日 
Key words : prosthetic speech appliance, velopharyngeal incompetence, misarticulation, oral cancer, dysarthria

\section{はじめに}

口腔・咽頭部は発声発語器官の一部を構成している ので，その器質的，機能的障害に起因する言語障害が 少なくない ${ }^{1,2)}$. それらの障害の治療には再建手術など の外科的治療あるいは機能訓練（いわゆる言語治療） のほかに，歯科的な技術を応用した補経的治療が適用 される ${ }^{3)}$.

これらの治療法の適応は原疾患によって異なる，原 則としては, 器質的な異常に対しては第一に外科的治 療が選択される。器質的な異常でも外科的に正常な機 能が得られない場合，あるいは，手術が適用となりに くい場合，および機能的な異常による場合には補綴的 治療と機能訓練の適用が検討される3.

本稿では補綴的治療の適応と効果について著者らの 教室で得られた結果を中心に述べる.

\section{補綴的発音補助装置の名称と種類}

補綴的治療に用いられる発音補助装置は「補綴的発 音補助装置」あるいは「スピーチエイド」と呼ばれて いる3,4. いわゆる「スピーチエイド」は広義では言語 障害を治療するための補助装置全体を指すが, 狭義に は後述の口蓋裂の形成術後などに見られる鼻咽腔閉鎖 機能不全の治療を主目的として鼻咽腔の空隙を補填す るための装置を呼ぶことがある ${ }^{4,5)}$. そのため, 本稿で は, 混乱を避けるために広義のスピーチエイドには「補 経的発音補助装置」の用語を用い, 狭義のものは「バ ルブ型スピーチエイド」の用語を用いる.
補綴的治療の方法抢よび補経的発音補助装置(以下, 発音補助装置) は補経される部位, 機能によって以下の

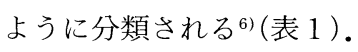

\section{1. 顔面補経, 顎補綴}

顔面, 頡骨の欠損を補緅物で補填し, 呼気の鼻漏出, 口腔共鳴の異常, 構音点の異常による言語障害を改善 する方法である. 主として, 悪性腫瘍などの術後の組 織欠損に適応される. 装置としては顔面の欠損を含め て補填するエピテーゼ (epithesis) と主として顎骨の 欠損を補填する䫟義芷がある(図 1)。顎骨の欠損の補 填を主目的とする場合には義顎，また，欠損部を閉鎖 する部分を栓塞部 (obturator) と呼ぶ.

\section{2. 口蓋補緅}

硬口蓋の組織欠損を義歯床によって補填し，口腔・ 鼻腔遮断不全あるいは口蓋の形態異常による言語障害 を改善する方法である. 口蓋裂や腫瘍などの術後組織 欠損に適応される，その装置は口蓋床と呼ばれる。

\section{3. 鼻咽腔部補綴}

鼻咽腔部の組織欠損あるいは機能障害によって鼻咽 腔閉鎖機能不全が認められる症例に適用される方法で ある. 装置はその形態と用途によって次の 3 種類に分 けられる。

1) 栓塞子型：軟口蓋栓塞子（soft palate obturator：SPO）：軟口蓋の破裂あるいは実質欠損をほと んど全域にわたり補填することにより, 発音の改善を 図る装置である(図 2 ).

2 ) バルブ型：バルブ型スピーチエイド（speech bulb prosthesis : SBP)：鼻咽腔閉鎖時に残存した咽

表 1 補経的発音補助装置の種類（道ら ${ }^{3)}, 2000$ 上り改変）

1. 顔面補綴, 顎補綴 (上顎補綴, 下顎補綴)：エピテーゼ, 顎義歯

2. 口蓋補綴：口蓋床

3 . 鼻咽腔部補綴

1 ) 栓塞子型 (Soft Palate Obturator : SPO)：軟口蓋栓塞子

2 ) バルブ型 (Speech Bulb Prosthesis: SBP)：バルブ型スピーチエイド（狭義のスピー チ・エイド)

3 ) 挙上子型：軟口蓋挙上装置 (Palatal Lift Prosthesis : PLP)

4. 舌補経

1 ) 舌接触補助床 (Palatal Augmentation Prosthesis : PAP)

2 ) 人工舌 (Artificial Tongue)

5 . 歯の補綴

6. 顎位の矯正装置：ゴム率引, ダイナミックポジショナー, チン・キャップ 


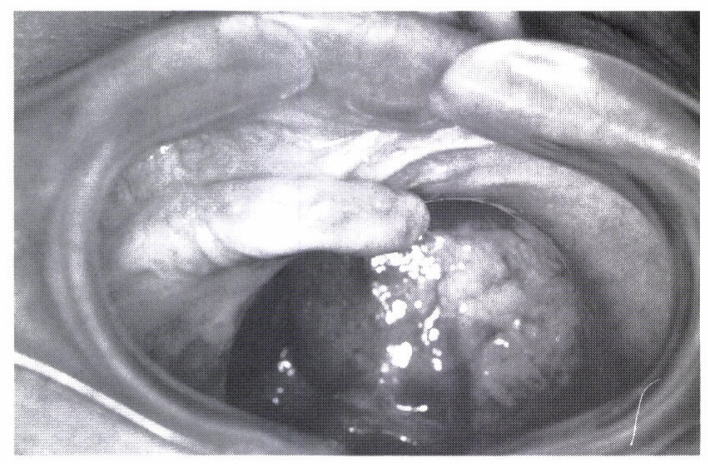

上顎久損症例の装着前の口腔内

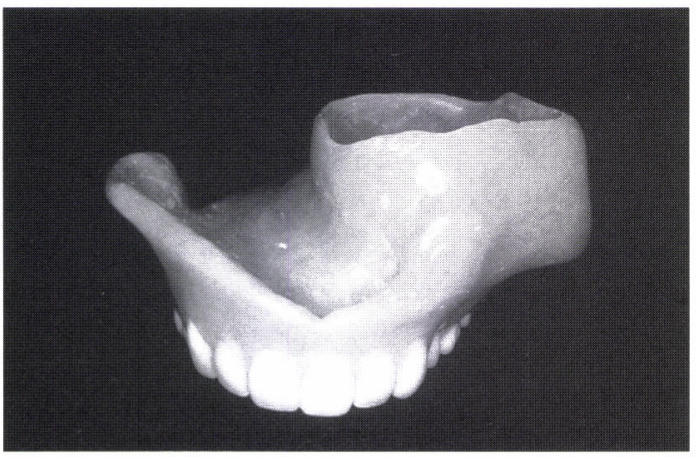

顎義㐘

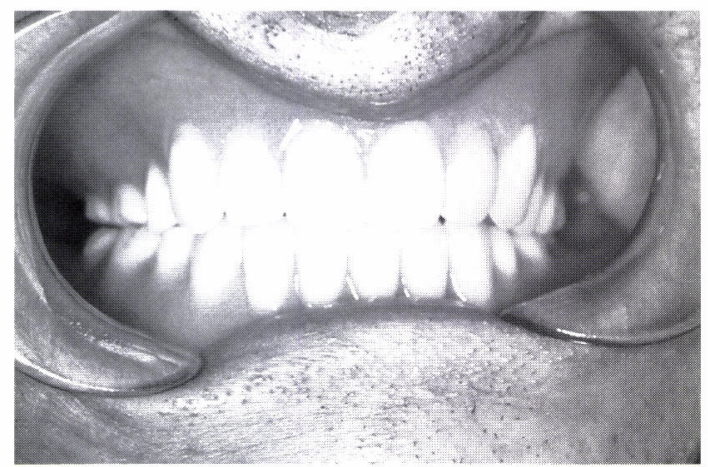

㖽義歯装着時の口腔内

図 1 㓵補綴

頭の空隙を人工物によって補い，口蓋咽頭括約筋群の 運動能力を賦活し，鼻咽腔閉銷機能の獲得を助けるこ とを目的とした装置である(図 3 )。

3 ）挙上子型：軟口蓋挙上装置（palatal lift prosthesis : PLP)：義歯の後方へ延長した挙上子によって軟 口蓋を人為的に挙上させて楀咽腔の空除を狭くし，奥 咽腔閉鎖機能を賦活, 獲得させる装置である(汹 4 ).

一般には軟口蓋が短い症例に対してはバルブ型スピ

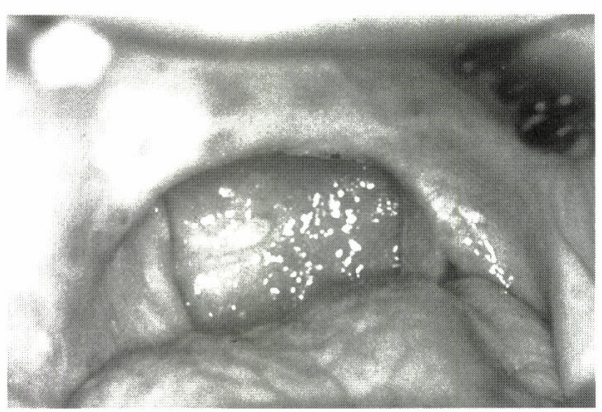

軟口蓋切除症例の装着前の口腔内

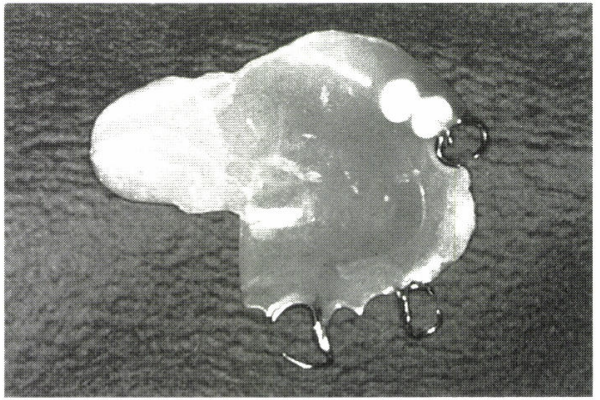

軟口蓋栓塞子

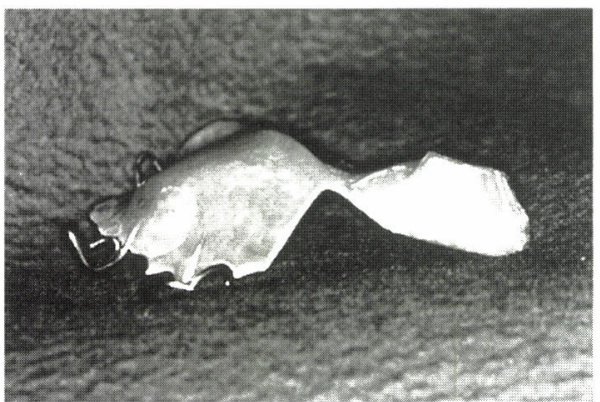

軟口蓋栓塞子

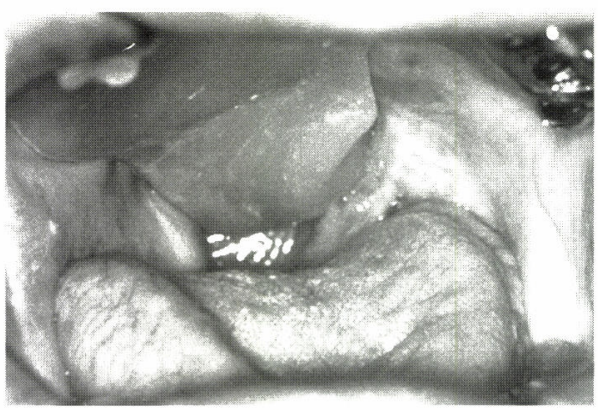

軟门蓋栓塞子装着時の口腔内

図 2 軟口蓋栓塞子 
一チエイド，軟门蓋の長さは十分だが運動性の乏しい 症例に対しては軟口蓋挙上装置，軟口蓋に实所欠損の ある症例に対しては軟口蓋栓塞子が適応される ${ }^{32}$.

\section{4.舌補緅}

舌の久損あるいは機能障害を補填する力法。

1) 舌接触補助床 (palatal augmentation prosthesis：PAP)：舌の運動障害あるいは欠損によ り秀と口蓋の接触が得られないときに舌の口蓋への接

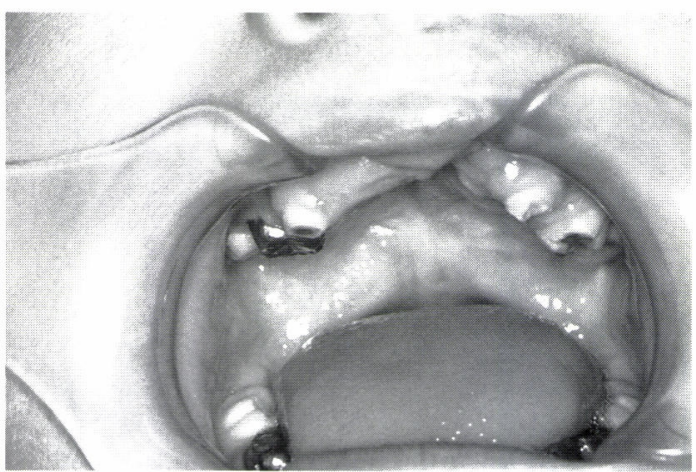

口蓋裂症例の装着前の口腔内

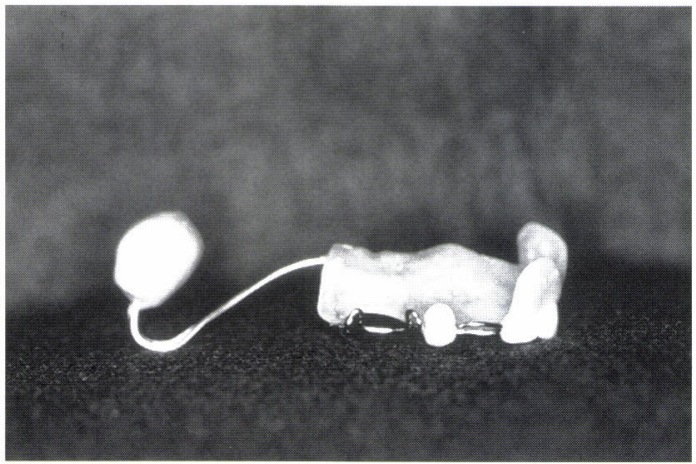

バルブ型スピーチエイド

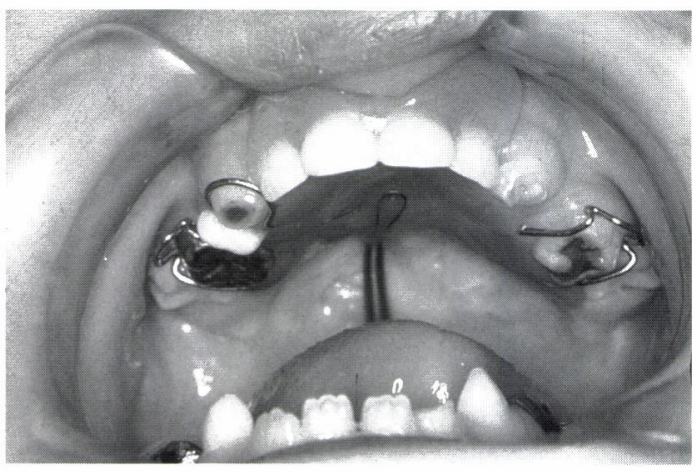

バルブ型スピーチエイド装着時の口腔内
触を補助し構音の改善を図ることを目的とした装置で ある、義歯床の口蓋部を肥厚させた形態をしている。 舌・底腫陽の術後後遺症などに適応される(図 5 )。

2 ) 人工舌 (artificial tongue)：舌の組織欠損に対 して欠損部に人工物を指入して機能の改善を図る装置 である7、現在，わが国ではほとんど使われていない。

\section{5. 歯の補緅}

歯の欠損による構音の異常を補綴によって改善する 方法。一般には発音補助装置に含めない。

1) 有床義歯：(わわる入れ歯，2）冠・橋義歯： クラウン，ブリッジ，継続歯などがある。

\section{6. 顎位の矯正装置}

安静時あるいは顎運動時の下顎の偏位を矯正し，一 定の位置に保持する装置である。発音時の顎の偏位を 矯正し，発音時の舌の位置を正常な位置に保つことを 目的とした装置。歯の矯正装置を利用したゴム率引や ダイナミックポジショナー，チン・キャップなどがあ る.下顎切除後の下顎偏位などに適用される。

これらのうち代表的なものについての適応と効果に ついて以下に述べる。

\section{顎補綴（上顎補綴）の適応と効果}

上顎癌などに対する手術後の上䫟欠損に対しては再 建手術が進歩した現在でも䫟補綴が多く適用されてい る ${ }^{81}$. 上顎欠損に対して顎補綴を適用した症例と再建

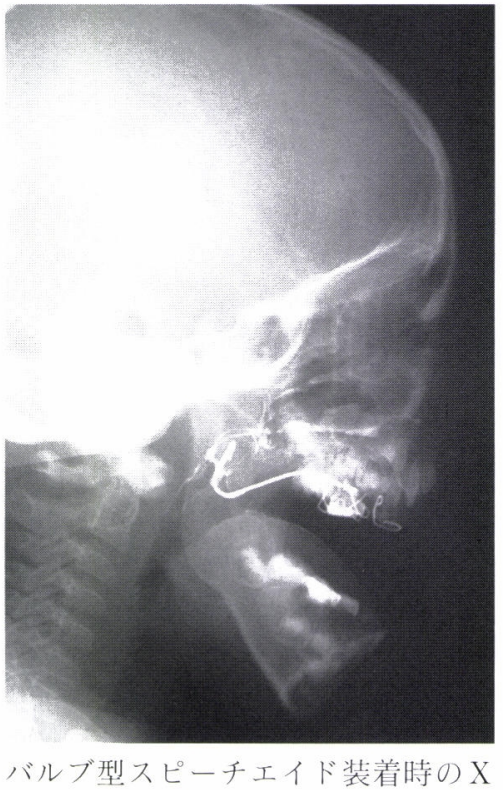

線与真

図 3 バルブ型スピーチエイド 
手術を行った症例とについて治療後の発語明膫度を比 較したところ，どちらの方法でも全体としての明膫度 は約 70\%で, 両者の間に差が認められないという結果

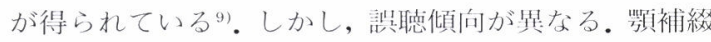

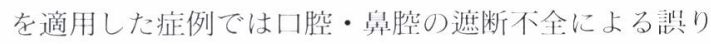
が多く，再建症例ではわたり音 (glides)などの構音の 䛊りが多く認められた（表2）。

上顎の顎義歯を適用した症例について装着前後の発

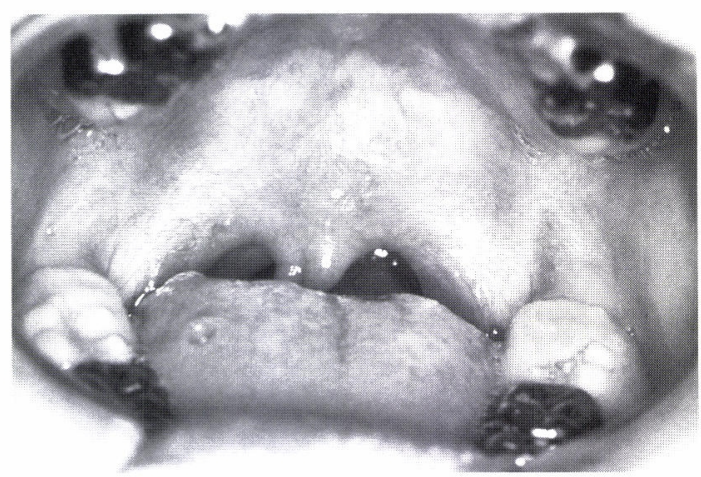

先天性番咽腔閉鎖不全症症例の装置装着前の口腔内

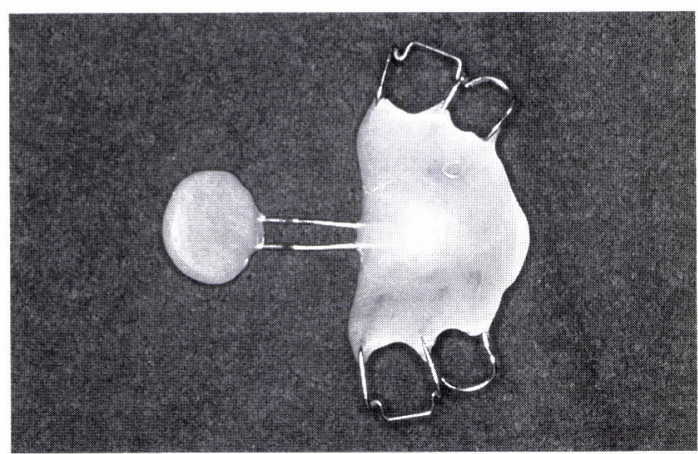

軟口蓋挙上装置

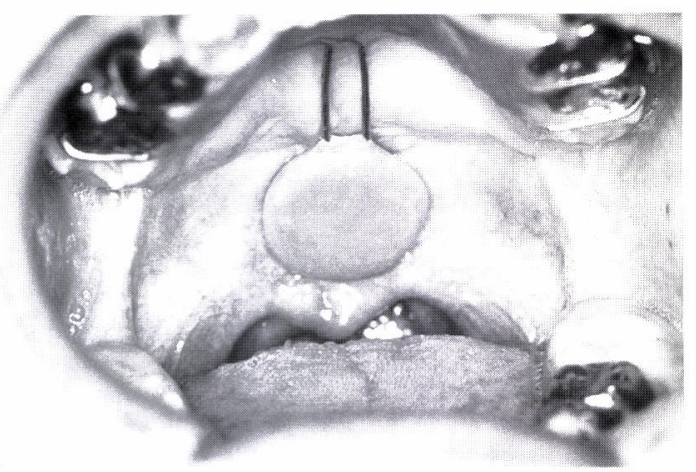

軟口蓋挙上装置装着時の口腔内
語明睹度を検査した結果では10,11)，顎義歯装着によつ ていずれの症例にも改善が見られるが，その程度は症 例によって異なっていた(表 3 )。従来から指摘されて いるように ${ }^{12}$, 切除範网が広い症例, 切除部位が軟口蓋 に及んでいる症例で言語機能の改善が不十分な症例が 多く見られるが，その原因をさらに詳細に見ると言語 機能の改善を妨げている最も大きな要因は, 発音時の 呼気の鼻漏出であることが明らかにされた。この原因 は2 つに分けられる。義㐘の十分な維持安定が得られ ないために口腔・鼻腔の遮断不全が生じ義歯の間隙か ら呼気が鼻腔へ漏出するものと, 手術侵襲による軟口 蓋の洀痕形成などによって鼻咽腔閉鎖機能不全が生じ ているものとである。対策としては，通常の顎義歯に よって言語所見が改善されない場合にはまず呼気の鼻 漏出の状態を観察する。その結果，前者の原因が考元 られる場合には補綴物の維持安定と辺緑封鎖を得るた めの処置，たとえばインプラント義歯の応用13)あるい は開口障害に対する処置を行う。後者の原因が考えら れる場合には顎義歯にバルブ型, 挙上子型などの鼻咽 腔部補経の形態を付与する(図 6 )。

\section{鼻咽腔部補綴の適応と効果}

\section{1 、蓋裂術後鼻咽腔閉鎖機能不全}

最近では, 几蓋形成手術の言語成績は改善され, 著

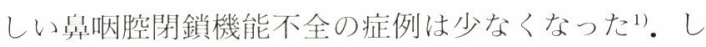

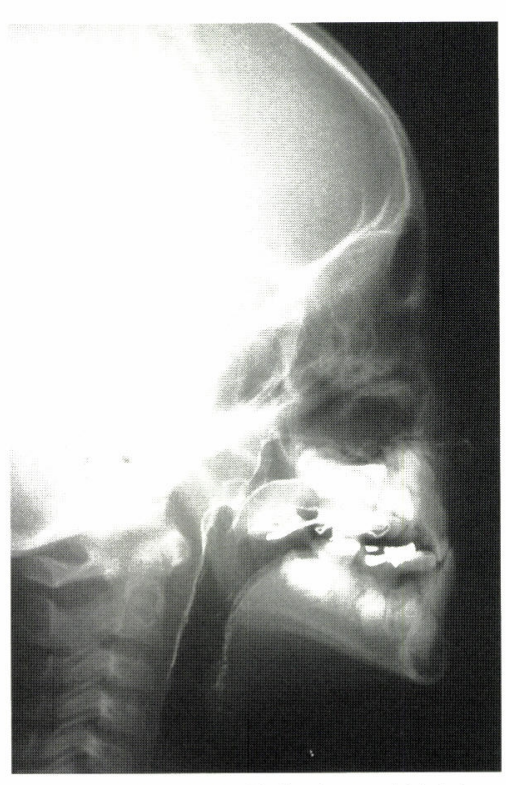

軟口蓋挙上装置装着時のX線写真

図 4 軟口蓋挙上装置 


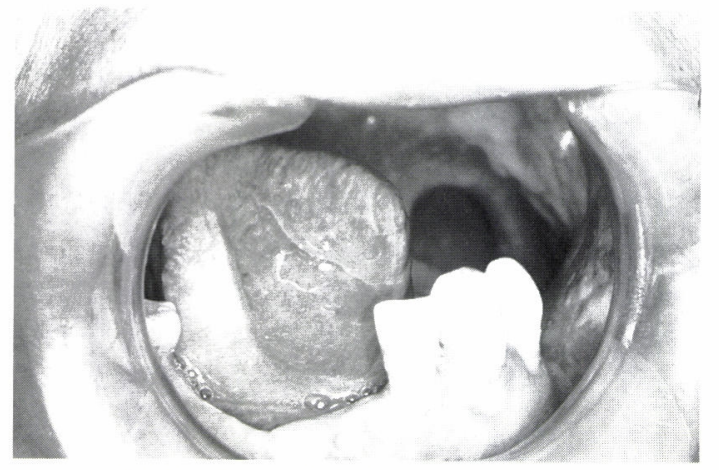

舌・底切除症例の装置装着前の口腔内（舌挙上時）

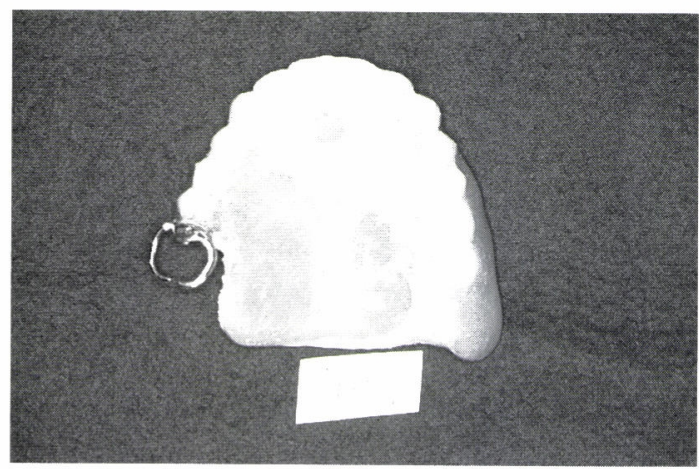

舌接触補助床を用いて取った [ki] 発音時のパラトグ ラム

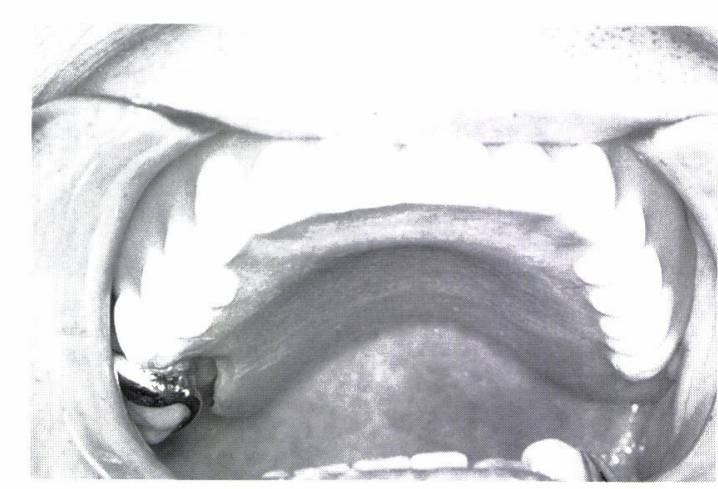

舌接触補助床装着時の口腔内 (安静時)

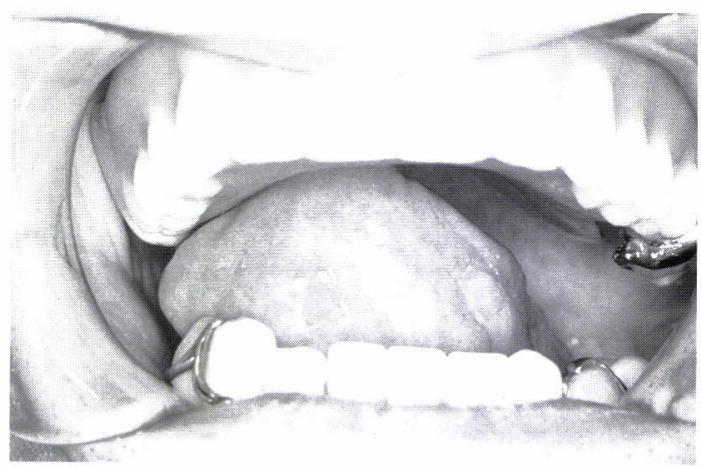

舌接触補助床装着時の口腔内（[sa］発音時）

図 5 舌接触補助床

表 2 上顎切除後の再建例と顎補経例における異聴傾向の比較 (Matsui, Y., et $\mathrm{al}^{9}{ }^{9}$, 1995)

\begin{tabular}{lcccc}
\hline \multicolumn{1}{c}{ 構音様式 } & \multicolumn{2}{c}{ 非再建 } & \multicolumn{2}{c}{ 腹直筋皮弁 } \\
& Plosives & Glides & Plosives & Glides \\
\hline 誸聴傾向 & & & & \\
Plosives & 32.7 & 19.0 & 41.3 & 55.6 \\
Fricatives & 2.8 & 0 & 9.0 & 0 \\
Affricatives & 0.5 & 2.7 & 7.6 & 0 \\
Glides & 10.2 & 0 & 11.7 & 0 \\
Nasals & 19.3 & 71.6 & 17.9 & 37.0 \\
Semivowels & 26.3 & 6.1 & 8.5 & 3.7 \\
Vowels & 8.2 & 0.6 & 4.0 & 3.7 \\
\hline
\end{tabular}

かし，現在でも日常臨床場面で鼻咽腔閉鎖機能が境界 領域のために正常な言語の獲得に支障のある症例にし ばしば遭遇する11.これらの症例に対してはバルブ型 か举上子型の鼻咽腔部補綴が適用される ${ }^{3)}$.

口蓋裂術後の鼻咽腔閉鎖機能不全症例 102 例に対す る鼠咽腔部補経の効果を 5 年以上の長期にわたって観
察した報告14)では，バルブ型あるいは挙上子型の発音 補助装置によって鼻咽腔閉鎖機能が改善される症例が 多く認められた。特に，早期に口蓋形成手術を行った 症例, 発音補助装置を 6 歳以下で装着した症例では装 着 1 年後に $95 \%$ が良好な鼻咽腔閉鎖機能を獲得し，そ の他の症例と比較して有意差をもって良好な成績であ 
表 3 上顎切除症例0)発浯明膫度を左右寸る因子 (大澤 ${ }^{10)}, 1990$ )

\begin{tabular}{|c|c|c|c|c|c|c|c|c|c|c|c|c|c|}
\hline \multirow{2}{*}{ 群 } & \multicolumn{11}{|c|}{ 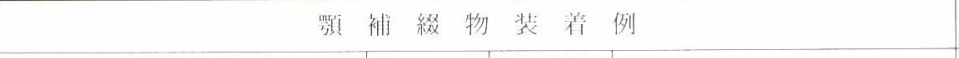 } & \multirow{2}{*}{\multicolumn{2}{|c|}{ 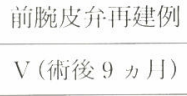 }} \\
\hline & \multicolumn{5}{|c|}{ I } & II & III & \multicolumn{4}{|c|}{ IV } & & \\
\hline 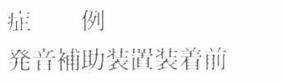 & 1 & 2 & 3 & 4 & 5 & 6 & 7 & 8 & 9 & 10 & 11 & 12 & 13 \\
\hline 総合正答率 $(\%)$ & 94.0 & 92.3 & 89.3 & 93.6 & 65.2 & 79.0 & 72.9 & 73.9 & 76.5 & 46.6 & 57.3 & $48.0^{*}$ & $70.2^{*}$ \\
\hline $\begin{array}{r}\text { 発部时 NFR }(\%) \\
\text { 発省補助装置装着後 }\end{array}$ & $2 \sim 8$ & $2 \sim 12$ & $4 \sim 6$ & $(n \sim 12$ & $6 \sim 40$ & $13 \sim 33$ & $(0 \sim 41$ & & $T \sim 27$ & $58 \sim 77$ & $37 \sim 65$ & $17 \sim 28$ & $10 \sim 52$ \\
\hline 総合正答率 $(\%)$ & & & & & & & & 92.9 & 84.3 & $58.2^{*}$ & 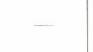 & 54.4 & 73.3 \\
\hline 発当時 NFR $(\%)$ & & & & & & & & & $1 \sim 25$ & $30 \sim 42$ & - & $11 \sim 18$ & $6 \sim 18$ \\
\hline 䫈補綴物の安定性 & 良好 & 良好 & 良好 & 良好 & 代是 & $\begin{array}{c}\text { 不良 } \\
\text { (総義歯) }\end{array}$ & $\begin{array}{c}\text { 不良 } \\
\text { (総義歯) }\end{array}$ & 良好 & 良好 & 良好 & 良好 & & \\
\hline
\end{tabular}

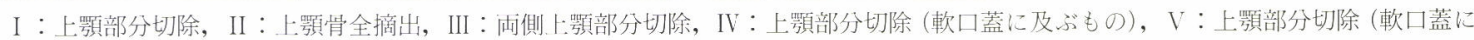
及ぶもの), NFR：呼気鼻漏出率，*：䫟補緅物 $(-)$

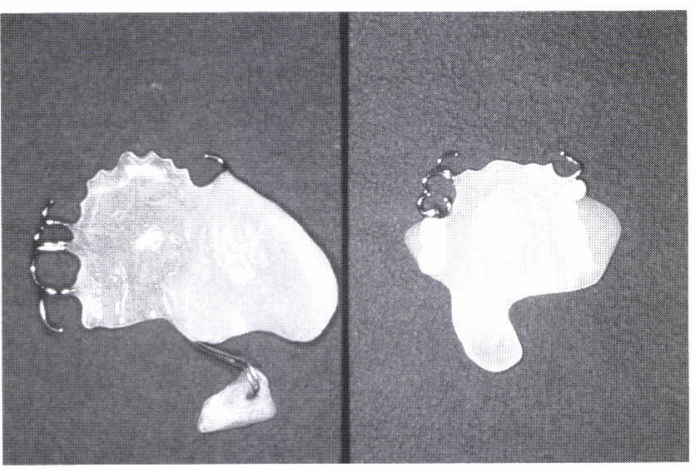

図 6 軟口蓋補経を併用した䞄義蔽

つた(表 4 )。また，鼻咽腔閉鎖機能が改善され，2 次 手術を行わずに装置を撤去することができた症例が早 期手術症例のうちの 40\%, 晚期手術症例のうちの $30 \%$ に見られることが明らかとなった（表 5，6）。これら の症例の装置装着から撤去までの期間は早い症例では 6 力月以内だが, 約半数の症例では 2 年以上を要して いたという結果であった（図７）。

本来, 発音補助装置は卑咽腔閉鎖機能を賦活・獲得 させ口蓋咽頭括約筋群の運動能力の変化に灾じて鼻咽 腔部を削除し，最終的には撤去することが目標である が，この目標ど㧈りに装置を撤去することができる症 例は少ないと考えられていた ${ }^{15)}$ しかし,山下らの長期 予後成績によって ${ }^{14}$, 口蓋裂術後の克咽腔閉鎖機能不 全症例のうち，3 歳以前の早期手術例で，㝠咽腔閉鎖 機能不全の程度が軽度な症例では, 発音補助装置を7 歳以前に装着すれば, 咽頭弁移植手術などの２次手術 を行わないでも補綴的治療と機能訓練で治淰させるこ とができるという論拠が示された。
発音補助装置を装着しても，最終的に装置を撤去す ることができなかった症例でも, 補経治療と機能訓練 によって言語障菁が改善された症例は, 外科的治療に よって，全例とも手術直後から良好な言語が得られた 1,14 16).この結果から, 観血処置の前段階としてロ蓋吠 頭括約筋群の賦活化, 正常言語の早期修得を目的とし

て適用されることも多い王,18).

発音補助装置は一種の異物であり，このような装置 を男唤腔に装着することによって患者に著しい不快感

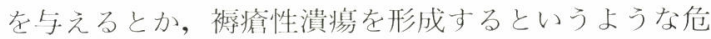
惧を抱くものがあるが，実際には一般の義歯と同様に ほとんど異物感なく使用できるものである。発音補助 装置を装着した患者 92 名に対し, 使用感についてのア ンケート調查を行った報告 ${ }^{15)}$ では，不快事項として違 和感, 疼痛, 食欲不振, 恥力損失, いびき, 取り扱い の不便さなどが指摘されているが, その発現頻度はき わめて低い值であった(表7).

\section{2 ，先天性鼻咽腔閉鎖不全症}

明らかな口蓋裂が認められないにもかかわらず，先 天的に鼻咽腔閉鎖機能不全を示す先天性鼻咽腔閉不全 症には本態の異なるいくつかの症型が含まれている 1,19) . 著者らは本疾患を軟口蓋造影側方頭部 X 線規格 写真に基ついて分類し，さらに，そのうちの特殊な症 型在顔面皇咽腔症候群（velo-facial syndrome）と定義 している19)(表 8).ここではその分類に従って述べる。 ただし，このときの報告で顔面鼻咽腔症候群とした症 例は, その後の今井らの研究201で, 染色体検査ができた 症例の全例がCATCH22 症候群であることが明らか になっている。

先大性鼻咽腔閉鎖不全症の鼻咽腔閉鎖機能不全に対 する治療は口蓋裂に準じて行う1,3).しかし，本症では 
表 4 口蓋裂の鼻咽腔閉鎖機能不全に対して発音補助 装置を装着した症例の手術時期・装着年噛と治療 成績（山下ら ${ }^{14)}$, 1998)

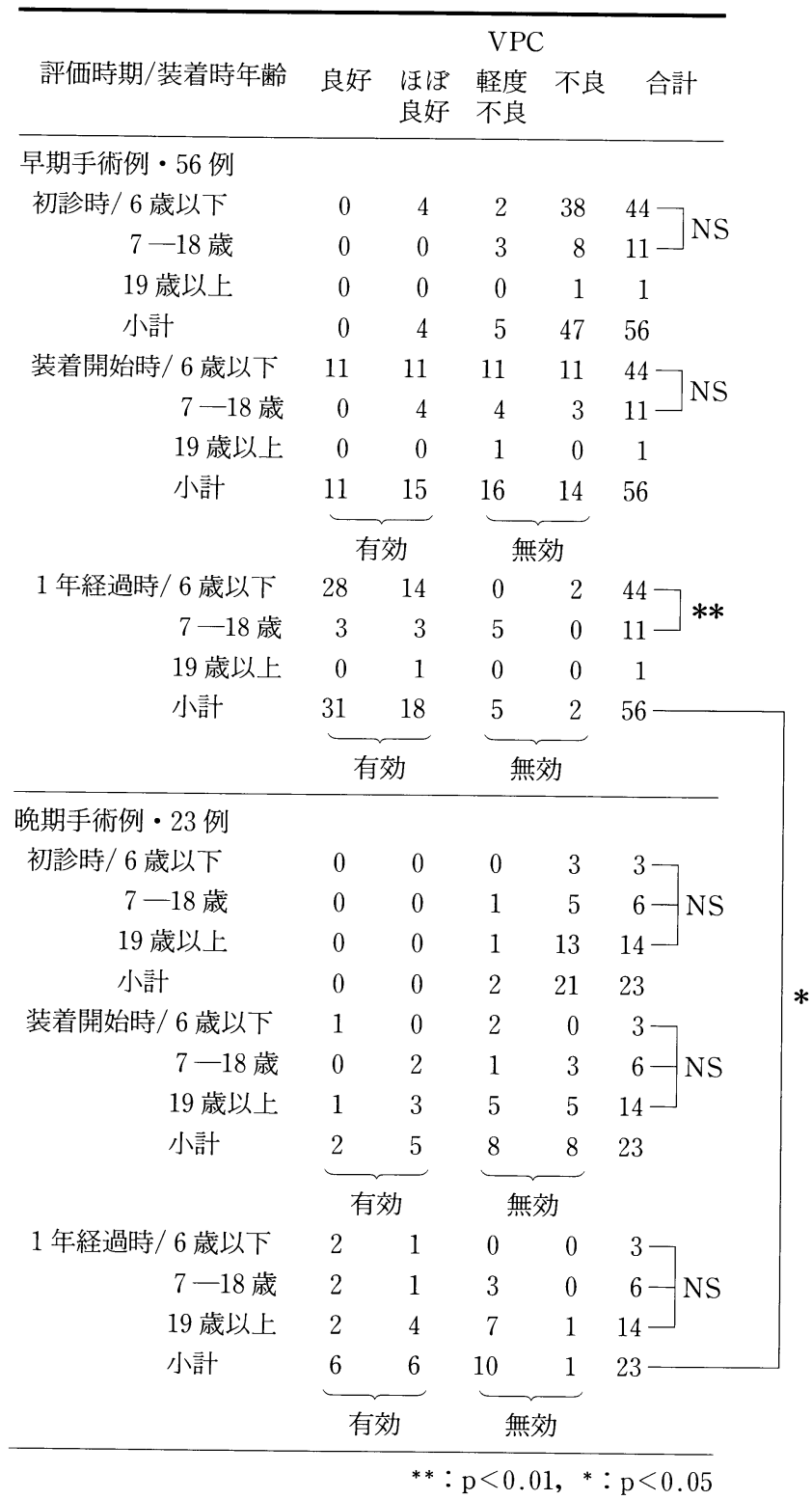

いわゆる粘膜下口蓋裂を除いて口蓋形態がほぼ整って いるので補経的治療が優先して行われる。まず，バル ブ型スピーチエイドあるいは軟口蓋挙上装置を装着し て機能訓練あるいは構音訓練を行う。鼻咽腔閉鎖機能 が改善し, ほぼ正常構音が獲得された段階で装置を撤 去するか外科的治療に移行する1,3) (図 8 ).

先天性鼻咽腔閉鎖不全症 31 例を顔面鼻咽腔症候群
と非症候群に分類し, 補経的治療の成績を口蓋裂症例 と比較した報告 ${ }^{16)}$ では, 顔面鼻咽腔症候群以外の先天 性鼻咽腔閉鎖不全症と口蓋裂症例はほぼ同様の結果が 得られている.しかし, 顔面鼻咽腔症候群はその他の 群と比較して予後良好例が少ない傾向であった（表 9 ).また, 装着後, 鼻咽腔閉鎖機能の改善率が $50 \%$ を 越えるまでの期間が，口蓋裂および先天性鼻咽腔閉鎖 
表 5 口蓋裂の鼻咽腔閉鎖機能不全に対して発音補 助装置を装着した早期手術症例の予後成績（山 下ら ${ }^{14)}$, 1998)

\begin{tabular}{|c|c|c|c|c|c|c|}
\hline \multirow{3}{*}{$\begin{array}{l}\text { 評価時期/ } \\
\text { 外科的治療の有無 }\end{array}$} & \multicolumn{6}{|c|}{$\mathrm{VPC}$} \\
\hline & 良好 & ほぼ & 軽度 & 不良 & 合計 & \\
\hline & & 良好 & 不良 & & & \\
\hline \multicolumn{7}{|l|}{ 初診時 } \\
\hline 外科的治療 $(-)$ & 0 & 4 & 4 & 11 & $19-$ & \multirow{3}{*}{$*$} \\
\hline 外科的治療 $(+)$ & 0 & 0 & 1 & 32 & $33-$ & \\
\hline 小計 & 0 & 4 & 5 & 43 & 52 & \\
\hline \multicolumn{7}{|l|}{ 装着開始時 } \\
\hline 外科的治療 $(-)$ & 2 & 10 & 5 & 2 & $19-$ & \multirow{2}{*}{ NS } \\
\hline 外科的治療 $(+)$ & 8 & 4 & 9 & 12 & $33 \neg^{\mathrm{T}}$ & \\
\hline \multirow[t]{2}{*}{ 小計 ～～～～～} & 10 & 14 & 14 & 14 & 52 & \\
\hline & \multicolumn{2}{|c|}{ 有効 } & \multicolumn{2}{|c|}{ 無効 } & & \\
\hline \multicolumn{7}{|l|}{1 年経過時 } \\
\hline 外科的治療 $(-)$ & 8 & 10 & 0 & 1 & $19 \square$ & \multirow{3}{*}{ NS } \\
\hline 外科的治療 $(+)$ & 21 & 7 & 3 & 2 & $33-1$ & \\
\hline \multirow[t]{2}{*}{ 小計 } & 29 & 17 & 3 & 3 & 52 & \\
\hline & \multicolumn{2}{|c|}{ 有効 } & \multicolumn{2}{|c|}{ 無効 } & & \\
\hline \multicolumn{7}{|l|}{ 撤去後 } \\
\hline 撤去後 1 年 & 7 & 9 & 3 & 0 & 19 & \\
\hline 術後 1 年 & 24 & 7 & 2 & 0 & 33 & \\
\hline \multirow[t]{2}{*}{ 小計 } & 31 & 16 & 5 & 0 & 52 & \\
\hline & \multicolumn{2}{|c|}{ 有効 } & \multicolumn{2}{|c|}{ 無効 } & & \\
\hline
\end{tabular}

不全症の非症候群では 6 力月以内なのに対し, 顔面鼻 咽腔症候群では 2 年以上 3 年以内と改善に長期間を要 することも明らかにされた(図 9 ).この結果について, 顔面鼻咽腔症候群では単に形態的な異常だけでなく, 神経・筋障害が認められるためであると考察している.

先天性鼻咽腔閉鎖不全症で発音補助装置を撤去でき た症例は装置装着 1 年以上で $19 \%$ であった ${ }^{16)}$. 外科的 治療の成績は補緅治療で良好な鼻咽腔閉鎖機能が得ら れた症例では術後すぐに良好な言語所見を示したが， 補経治療で良好な鼻咽腔閉鎖機能が得られなかった症 例では術後に良好な言語所見は得られなかった。これ らの症例では, 術後に再度, 発音補助装置を装着し, 長期間にわたって言語治療を行うことになる。

\section{3 . 中咽頭欠損}

悪性腫瘍による中咽頭切除症例のうち軟口蓋（咽頭 上壁）および咽頭側壁に切除範囲が及ぶ症例に対して は遊離皮弁が適用され，良好な成績が得られてい $る^{21 \sim 23)}$. しかし, 現在でも術後に鼻咽腔閉鎖機能不全
表 6 口蓋裂の鼻咽腔閉鎖機能不全に対して発音補 助装置を装着した晚期手術症例の予後成績（山 下ら ${ }^{14}$, 1998)

\begin{tabular}{|c|c|c|c|c|c|}
\hline \multirow{3}{*}{$\begin{array}{l}\text { 評価時期/ } \\
\text { 外科的治療の有無 }\end{array}$} & \multicolumn{5}{|c|}{ VPC } \\
\hline & 良好 & ほぼ & 軽度 & 不良 & 合計 \\
\hline & & 良好 & 不良 & & \\
\hline \multicolumn{6}{|l|}{ 初診時 } \\
\hline 外科的治療 $(-)$ & 0 & 0 & 2 & 2 & 4 \\
\hline 外科的治療 $(+)$ & 0 & 0 & 0 & 9 & 9 \\
\hline 小計 ～～～～～ & 0 & 0 & 2 & 11 & 13 \\
\hline \multicolumn{6}{|l|}{ 装着開始時 } \\
\hline 外科的治療 $(-)$ & 1 & 2 & 1 & 0 & 4 \\
\hline 外科的治療 $(+)$ & 0 & 3 & 3 & 3 & 9 \\
\hline \multirow[t]{2}{*}{ 小計 } & 1 & 5 & 4 & 3 & 13 \\
\hline & \multicolumn{2}{|c|}{ 有効 } & \multicolumn{2}{|c|}{ 無効 } & \\
\hline \multicolumn{6}{|l|}{1 年経過時 } \\
\hline 外科的治療 $(-)$ & 2 & 1 & 1 & 0 & 4 \\
\hline 外科的治療 $(+)$ & 2 & 4 & 3 & 0 & 9 \\
\hline \multirow[t]{2}{*}{ 小計 } & 4 & 5 & 4 & 0 & 13 \\
\hline & \multicolumn{2}{|c|}{ 有効 } & \multicolumn{2}{|c|}{ 無効 } & \\
\hline \multicolumn{6}{|l|}{ 撤去後 } \\
\hline 撤去後 1 年 & 0 & 2 & 2 & 0 & 4 \\
\hline 術後 1 年 & 6 & 1 & 2 & 0 & 9 \\
\hline \multirow[t]{2}{*}{ 小計 } & 6 & 3 & 4 & 0 & 13 \\
\hline & \multicolumn{2}{|c|}{ 有効 } & \multicolumn{2}{|c|}{ 無効 } & \\
\hline \multicolumn{6}{|l|}{ 継続使用（ 5 例） } \\
\hline \multirow{3}{*}{ 評価時期 } & \multicolumn{5}{|c|}{ VPC } \\
\hline & 良好 & ほぼ & 軽度 & 不良 & 合計 \\
\hline & & 良好 & 不良 & & \\
\hline 初診時 & 0 & 0 & 0 & 5 & 5 \\
\hline 装着開始時 & 1 & 0 & 3 & 1 & 5 \\
\hline \multirow[t]{2}{*}{1 年経過時 } & 2 & 1 & 2 & 0 & 5 \\
\hline & \multicolumn{2}{|c|}{ 有効 } & \multicolumn{2}{|c|}{ 無効 } & \\
\hline
\end{tabular}

が生じる症例が少なくない24).これらの症例に対して バルブ型スピーチエイド，軟口蓋挙上装置，栓塞子な どの鼻咽腔部補綴が鼻咽腔の形態, 機能に応じて適用 される25 29) (図 10).

藤田ら ${ }^{29}$ は再建手術を行っても言語機能が改善され なかった症例に対して発音補助装置を装着して言語成 績を検討している。そののかで発音補助装置の適用基 準として軟口蓋の実質欠損が大きい症例には栓塞子 型, 軟口蓋の連続性が回復している症例にはバルブ型, 軟口蓋の連続性が回復し長さも十分な症例では挙上子 


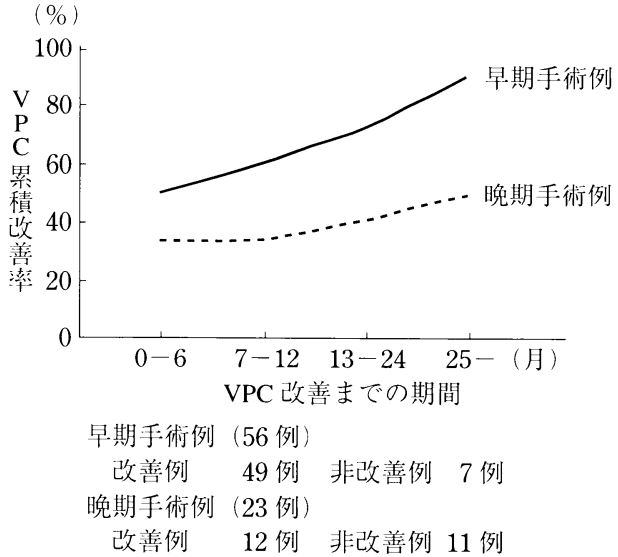

図 7 口蓋裂症例における補経的発音補助装 置装着から鼻咽腔閉鎖機能改善までの 期間（山下ら ${ }^{14)}, 1998$ )
表 7 バルブ型スピーチエイド装着 後の不快事項 (吉田ら ${ }^{15)}, 1979$ ) スピーチ・エイドの不快事項 (アンケート)

\begin{tabular}{ll}
\hline 違和感 & 3 \\
疼痛 & 3 \\
食欲不振 & 2 \\
聴力損失 & 2 \\
いびき & 1 \\
不便 & 1 \\
\hline
\end{tabular}

表 8 先天性鼻咽腔閉鎖不全症の分類（吉田ら ${ }^{199} ， 1982 ）$
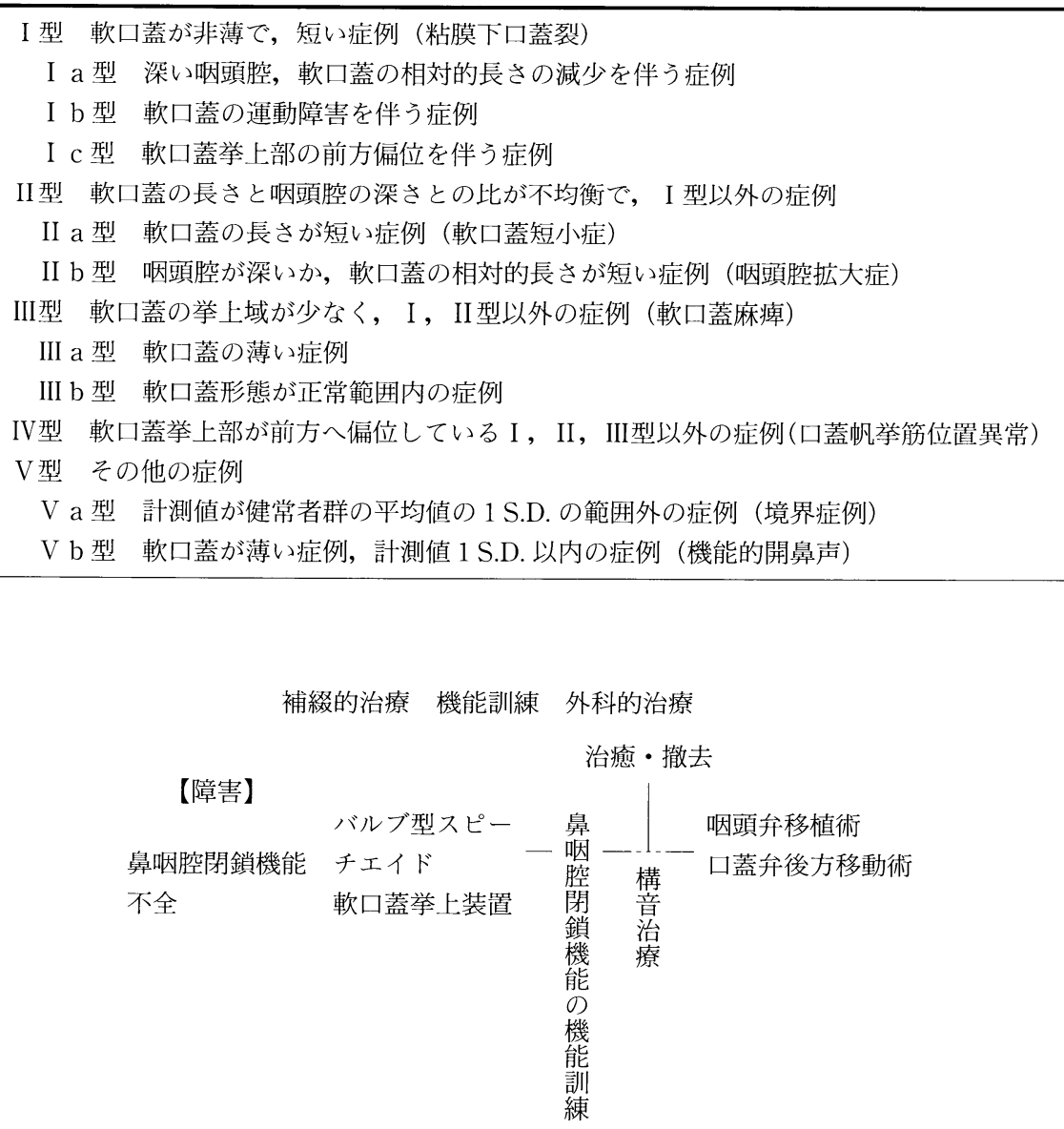

図 8 先天性鼻咽腔閉鎖不全症に対する言語治療の方針（道 $\left.ら^{3)}, 2000\right)$ 
表 9 先天性鼻咽腔閉鎖不全症の治療法と治療成績（今井ら ${ }^{16)}$, 1988）

\begin{tabular}{|c|c|c|c|c|c|c|}
\hline $\begin{array}{l}\text { 造影セファロ } \\
\text { による分類型 }\end{array}$ & 治療法 & 症例数 & 良好 & $\begin{array}{l}\text { 療後の鼻口 } \\
\text { ほぼ良好 }\end{array}$ & $\begin{array}{l}\text { 腔閉鎖機能 } \\
\text { 軽度不良 }\end{array}$ & 不良 \\
\hline \multirow[t]{4}{*}{ I 型 } & 補綴的治療* & 10 & $3(1)$ & $2(1)$ & 4 & 1 \\
\hline & 補綴＋外科 & 4 & 1 & & 2 & 1 \\
\hline & 外科的治療* & 6 & 3 & & 2 & 1 \\
\hline & 言語治療のみ & 1 & 1 & & & \\
\hline \multirow[t]{2}{*}{ II型 } & 補緅的治療* & 7 & 4 & 1 & $1(1)$ & 1 \\
\hline & 補綴＋外科 & 3 & 1 & & & 2 \\
\hline III型 & 補綴的治療 & 3 & $3(1)$ & & & \\
\hline \multirow[t]{2}{*}{ IV型 } & 補綴的治療* & 2 & & $1(1)$ & $1(1)$ & \\
\hline & 補緅＋外科 & 1 & 1 & & & \\
\hline \multirow[t]{2}{*}{$\mathrm{V}$ 型 } & 補緅的治療 & 1 & & & 1 & \\
\hline & 言語治療のみ & 2 & 2 & & & \\
\hline
\end{tabular}

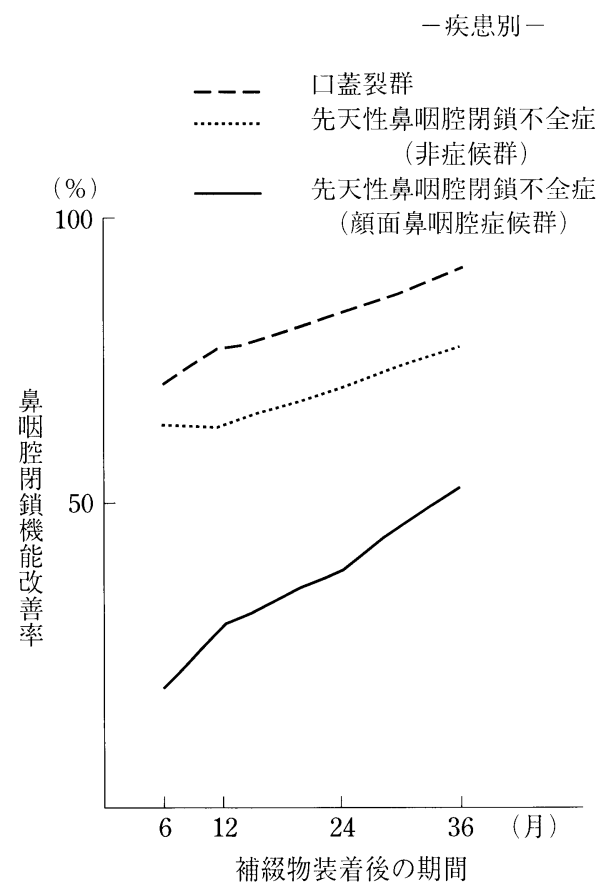

図 9 先天性鼻咽腔閉鎖不全症における補 経的発音補助装置装着から鼻咽腔閉 鎖機能改善までの期間（今井ら ${ }^{16)}$, 1988)

型が適応されると述べている．治療成績は鼻咽腔の形 態扔よび切除範囲と関連が見られ, 軟口蓋後縁の連続 性の有無によって治療成績が左右されると述べている (表 10).

Yoshida ら ${ }^{30)}$ は軟口蓋欠損による言語障害を再建手
術症例と補経的治療症例で比較している，その結果で も軟口蓋後縁の連続性が保たれている症例では発音補 助装置のみによって良好な言語成績が得られるが, 軟 口蓋の後縁まで切除した症例では発音補助装置のみで は良好な成績は得られず，再建手術と補経的治療の併 用が必要であると述べている(表 11)。結局, 再建手術 が進歩しても補綴的治療は必要であり, 症例によって 両者の治療法の適応を使い分けるべきであると結論づ けている.

\section{4. 運動障害性構音障害}

運動障害性構音障害患者の鼻咽腔閉鎖機能不全につ いても口蓋裂などの器質的疾患によるものと補綴的治 療の適応は同様である ${ }^{3,31,32)}$. しかし，後天性の運動障 害性構音障害患者に対しては外科的治療を適応して良 好な成績が得られたとの報告は少ない33,34).特に, 脳血 管障害などの既往のある患者に対しては手術のリス ク, 進行性病変への対応, 患者の要求, 手術成績の確 実性などをも考えて，現在は補経的処置を第一選択と すべきであると考えられる ${ }^{31 \sim 35)}$.

本症患者では鼻咽腔の形態には異常がないので軟口 蓋挙上装置が適用される。その適応基準は(1)鼻咽腔閉 鎖機能不全を主徵とした構音障害, (2)口唇・舌などの運 動麻痺, 発声障害, プロソディーの障害が軽度から中 等度，(3)曣下障害が見られないか軽度，(4)義歯床を維 持するための義歯が残存している，(5)義歯の着脱およ び清掃ができる状況であることなどである ${ }^{31,32,35)}$.

道ら ${ }^{32}$, 山下 ${ }^{36}$ は鼻咽腔閉鎖機能不全を伴う後天 性運動障害性構音障害患者について軟口蓋挙上装置の 効果を検討したところ，70～80\%の症例で鼻咽腔閉鎖 機能および発声発語機能が改善されたと述べている 


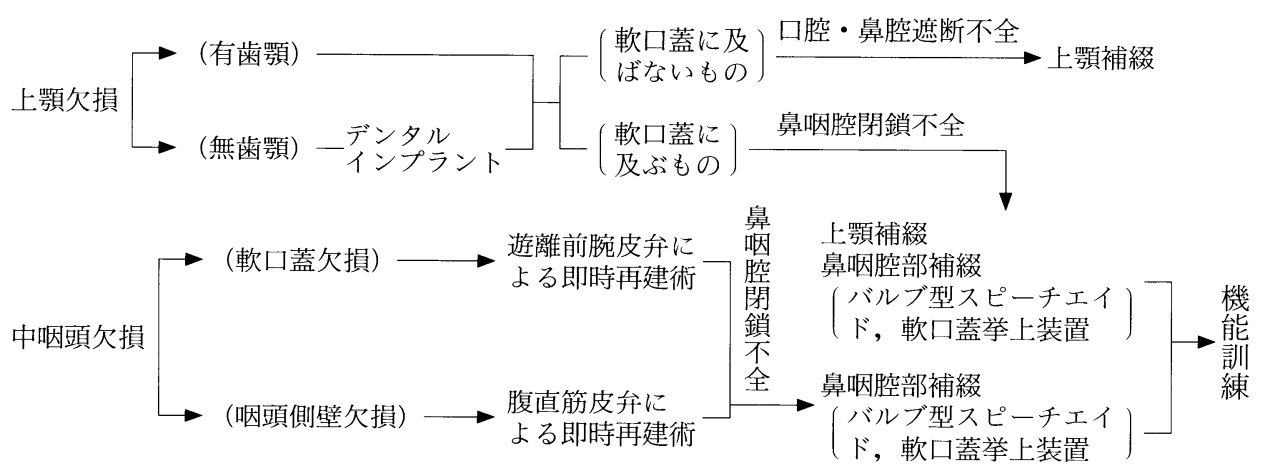

図 10 上頒，中咽頭欠損症例に対する言語治療の方針（道ら ${ }^{3)}, 2000$ )

(図 11，表 12).しかし，臨床評価の基準は独特の緩や かなもの(表 13) を用いている3).その理由として本症 患者のような場合には，健常人と同等なレベルまでの 言語機能の回復を目的とした治療は必ずしも適切では なく, 症例の障害の程度に応じて残存した機能を最大 限に生かすことを目的とすべきだからであると述べて いる.たとえば，鼻咽腔閉鎖機能については主として 口蓋裂患者を対象とした一般的な評価基準に従えば装 置装着後も良好と判定できない症例が多い.しかし， 本症においては鼻咽腔がある程度狭小化されるだけで も呼気持続時間, 発声持続時間の延長などの効果をも たらすことがあり，これによって患者が自覚的に発声 が容易になったという評価をすることが多い.

単音節発語明瞭度については, 本装置により約半数 の症例では $10 \%$ 以上改善し, 特に言語障害の程度が中 等度から重度の症例が多かった。しかし，単音節発語 明瞭度ではほとんど改善が見られないような症例で も, 日常会話では,「話が通じるようになった.」とい う自覚的な印象を持っているものがあり, 本装置の効 果は発語明瞭度の変化だけでは判断できないことが多 い.また，一般に行われている会話明瞭度の 5 段階判 定では明らかな改善と評価できない場合でも患者が満 足していることがある，たとえば一息に話せる語が多 くなったとか, 会話をしても疲れなくなったというよ うな患者の評価が得られている。

このような場合には概括的な改善過程の評価が必要 になる，本報では患者あるいは家族の主観的な評価に よる満足度と言語聴覚士の主観的評価による総合評価 が, 最も適切なようであると考察している。これらの 評価は発語明瞭度および呼気持続時間の変化と比較的 一致した結果を示し, この 2 つの検査值のどちらかに 改善が見られると患者および言語聴覚士は良い評価を するようであると述べている。
構音障害の重症度別に見ると, 構音障害が軽度な症 例では構音機能の改善はわずかであるが, 発声持続時 間, ブローイング時間, 交互運動能力が改善される者 が多く, 発声が楽になったと自覚する者が多い. 中等 度障害の症例では半数以上で鼻咽腔閉鎖機能だけでな く, 発声発語機能および構音機能も改善される. 重度 障害症例では構音機能の改善と発声機能が改善され, 話しやすくなった自覚する者が多い.

このように, 本装着による効果は症例によってさま ざまであり, 鼻咽腔閉鎖機能の改善だけではなく, 発 声発語機能, 構音機能の改善など広範囲に及んでいる ものと考えられる.

装置装着後の経過については, 装着直後には改善し ないことが多いが, 6 力月から 1 年の間, 定期的に機 能訓練と構音訓練を行うと鼻咽腔閉鎖機能が改善され る(図 12).頭部X線規格写真における計測で非装着時 の軟口蓋一咽頭後壁間距離（V-P gap）の減少が見ら れた症例も見られ, 装置装着による鼻咽腔閉鎖機能の 賦活化も期待できる.

本装置の装着期間は, 平均すると 1 年程度の症例が 多く, 鼻咽腔閉鎖機能不全は完全には改善しないもの の, 日常会話には支障がない程度まで改善されると撤 去できると考えられる。この結果から, 本装置は, 患 者にとってできるだけ良い条件で言語治療が受けられ るようにするための補助的装置とも考えられる.また, 本装置を装着することによって改善する点としない点 を患者に説明して理解させ, 治療に対する患者の動機 づけを高く保ち続けることが, 治療の成功に繫がると 考えられる.

本装置装着後の不快症状としては顕著な症状を認め た報告はない. 装置装着直後には大多数の症例で絞扼 反射が認められるが, 一度装置に適応し, 義歯の維持 が良好であれば軟口蓋を刺激することはない。患者が 


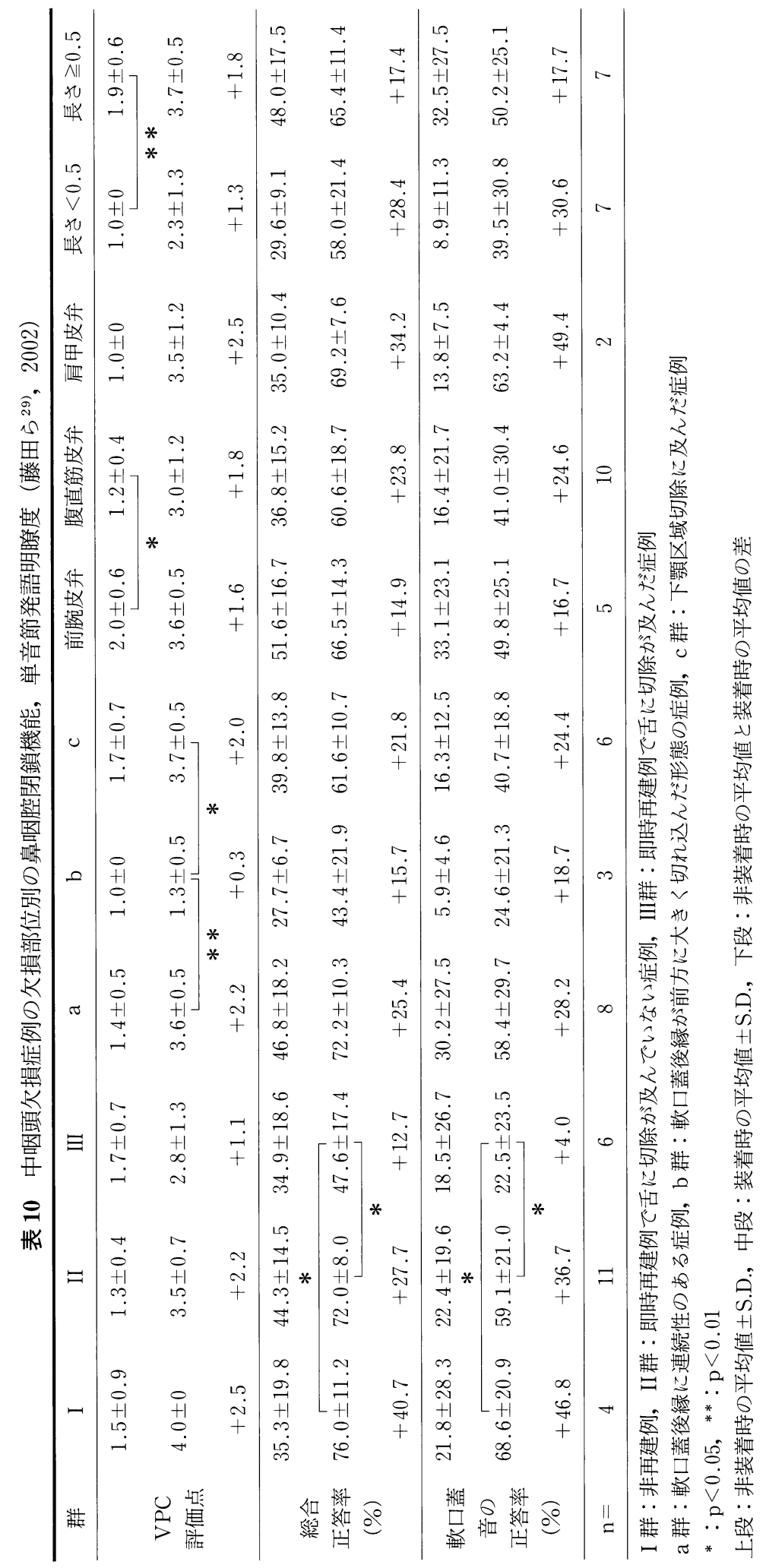


表 11 軟口蓋欠損症例の術後単音節発語明瞭度（Yoshida, H., et a ${ }^{30)}$, 1993)

\begin{tabular}{cccccc}
\hline Group & $\begin{array}{c}\text { Patient } \\
\text { No. }\end{array}$ & Preoperative & $\begin{array}{c}\text { Postoperative } \\
\text { withont } \\
\text { Obturator }\end{array}$ & $\begin{array}{c}\text { Postoperative } \\
\text { with } \\
\text { Obturator }\end{array}$ & $\begin{array}{c}\text { Postoperative } \\
\text { with Special } \\
\text { Obturator }\end{array}$ \\
\hline \multirow{2}{*}{1} & 1 & 86.1 & 29.0 & 73.9 & 92.9 \\
& 2 & - & 13.2 & 57.3 & - \\
& 3 & 89.3 & 31.1 & 64.3 & - \\
& 4 & 91.0 & 44.1 & 76.5 & - \\
& 5 & 88.5 & 21.3 & 46.6 & 45.0 \\
& 6 & 70.4 & 40.8 & - & 78.3 \\
& 9 & 93.0 & 70.2 & - & - \\
& 8 & 92.2 & 74.2 & - & - \\
\hline
\end{tabular}

Group 1 : 軟口蓋後縁が残存している症例, Group 2：軟口蓋の後緑まで切除した症例, 症例 6-10：即時再建症例

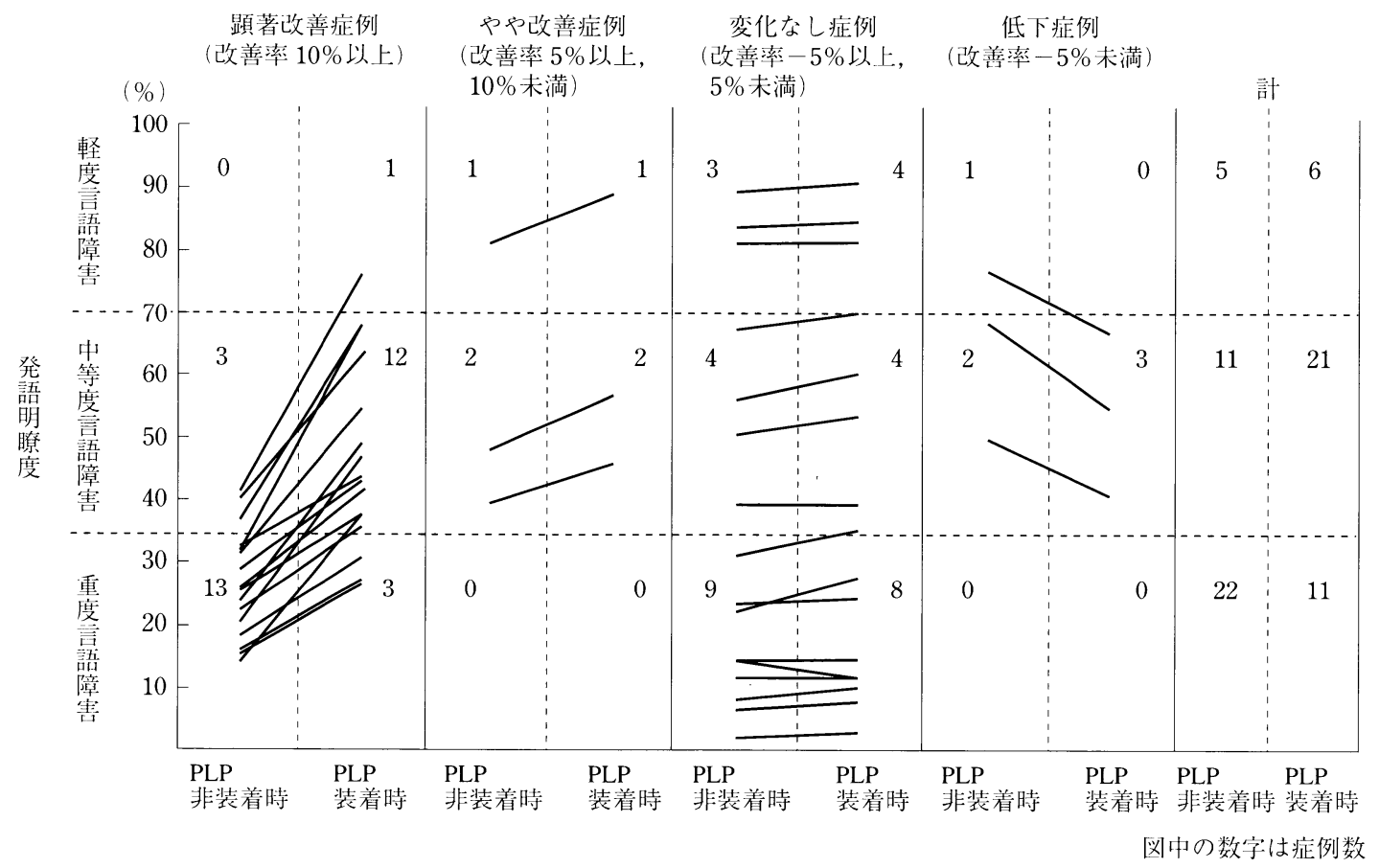

図 11 後天性運動障害性構音障害症例への軟口蓋挙上装置装着による発語明瞭度の変化（山下ら $\left.{ }^{36)}, 1990\right)$

「不満」と判定した症例では異物感が強く流涎が多くな ったとか，鼻閉感が強く息苦しいという症状を訴える ものがあるが，このような不快症状は装着後の訓練， 患者の努力，義歯の調整などによって軽快するものが 多い.

\section{舌接触補助床の適応と効果}

悪性腫瘍による舌・口底切除後には遊離皮弁あるい は筋皮弁による再建が行わ机る ${ }^{21,22)}$. 通常は舌の $2 / 3$ 切除までであれば遊離皮弁によって十分に構音機能が 改善される ${ }^{21,22,38 \sim 42)}$. しかし, 舌亜全摘以上の切除例で は筋皮弁で舌の形態を整えても構音障害が残存するこ 
表 12 後天性運動障害性構音障害症例への軟口蓋挙上装置装着によるblowing 検査所見と発語明瞭度の変化 (山下ら ${ }^{36}$, 1990)

\begin{tabular}{|c|c|c|c|c|c|}
\hline & $\begin{array}{l}\text { 顕著改善例 } \\
\text { (改善率 } \\
\text { 10\%以上) }\end{array}$ & $\begin{array}{c}\text { やや改善例 } \\
\text { (改善率 5\%以上, } \\
10 \% \text { 未満) }\end{array}$ & $\begin{array}{c}\text { 語 明 瞭 度 } \\
\text { 変化なし例 } \\
\text { (改善率-5\%以上, } \\
5 \% \text { 未満) } \\
\text { ( })\end{array}$ & $\begin{array}{c}\text { 低下例 } \\
\text { (改善率- } 5 \% \text { 未満) }\end{array}$ & 計 \\
\hline \multicolumn{6}{|l|}{ blowing 検査 } \\
\hline 顕著改善例 ${ }^{1}$ (25) & 10 & 2 & 8 & 1 & 21 \\
\hline やや改善例 ${ }^{2}$ (9) & 1 & 1 & 1 & 0 & 3 \\
\hline 変化なし例 ${ }^{3}(7)$ & 3 & 0 & 3 & 0 & 6 \\
\hline 低下例 $\left.{ }^{4} \quad （ 2\right)$ & 0 & 0 & 1 & 1 & 2 \\
\hline
\end{tabular}

数字は症例数，（）は blowing 検査可能であった症例数

${ }^{1}$ : blowing 時間が 3 秒以上延長し, blowing ratio が 0.2 以上増加した症例

${ }^{2}$ : blowing 時間が 1 秒以上 3 秒未満延長した症例

${ }^{3}$ : blowing 時間および blowing ratio が変化しなかった症例

${ }^{4}$ : blowing 時間抢よび blowing ratio が低下した症例

表 13 鼻咽腔閉鎖機能の判定基準一後天性の機能不 全一（道ら $\left.{ }^{25)}, 2000\right)$

\begin{tabular}{c|c|c|c}
\hline 総合判定 & $\begin{array}{c}\text { 子音の歪み } \\
(/ \mathrm{ba} /)^{\mathrm{a}}\end{array}$ & $\begin{array}{c}\text { 開鼻声 } \\
(/ \mathrm{i} /)^{\mathrm{b}}\end{array}$ & $\begin{array}{c}\text { ストロー吹きの鼻孔 } \\
\text { 開放時・閉鎖時の泡 } \\
\text { 立て持続時間の比 } \\
\text { (blowing ratio) }^{\mathrm{c}}\end{array}$ \\
\hline 良好 & $(-)$ & $(-)$ & 0.8 以上 \\
\hline ほぼ良好 & $( \pm)$ & $(-)$ & \\
& $( \pm)$ & $( \pm)$ & 0.2 以上 \\
軽度不良 & $( \pm)$ & $(+)$ & 0.8 未満 \\
\hline 不良 & $(+)$ & $(+)$ & $(+)$ \\
\hline
\end{tabular}

$\mathrm{a}($ - ) : なし, $( \pm)$ : 少しあり（鼻雑音が聴取される，

$(+):$ あり $(/ \mathrm{b} /$ と $/ \mathrm{m} /$ の中間の音 $)$,

$(++)$ : 重度あり (通鼻音 $/ \mathrm{m} /$ 亿聴取される)

${ }^{\mathrm{b}}(-)$ : なし, $( \pm) ：$ 少しあり, $(+)$ ：あり，

$(++):$ 重度あり

c鼻孔開放時の計測時間

鼻孔閉鎖時の計測時間

とが多い。切除範囲が狭い症例でも再建が不十分な症 例，再建しても再建舌の体積が小さい症例，および可 動性の不良な症例では術後の構音障害が著しい ${ }^{43,44)}$. これらの舌・口底の切除による構音障害の主な原因は 舌の運動性の低下によるものなので45,46)，これを補助 するために舌接触補助床が適用される (図 13).

構音検查を行って改善目的とする音を決定し，その 音の構音点を考慮してパラトグラムあるいは聴覚的印
象を参考にして口蓋床を盛り上げる，また，患者自身 の口腔内の感覚や聴覚印象からも調整に有用な情報が 得られることがある。形態の決定に際しては，製作に あたる歯科医師と言語聴覚士が緊密に連携を取ること が重要である. 舌接触補助床は嶼下障害の治療にも適 応されるが，言語障害に適用される場合と嬩下障害に 適用される場合とでは形態が一致しないことがあるの で，言語障害治療を目的とする場合には嶼下時に違和 感が出ないように調節する，完成後は定期的に構音の 評価を行い，舌運動機能の改善に合わせて口蓋床を削 合し，徐々に薄くしてゆく ${ }^{3)}$.

MRI を応用して舌・口底切除症例の声道形態を観察

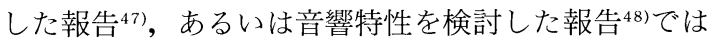
舌接触補助床によって明らかに声道形態あるいは音響 特性が改善されている。

わが国で最初に多数例についての臨床成績を報告し たのは齋藤らである ${ }^{49}$.それによると, 本装置装着によ つて単音節発語明瞭度が 1.8 2 $2 \%$ 改善し, 舌音の中 で舌尖音が舌後方音よりも有意に高い改善が得られて いる.適応の良好な症例は舌の切除範囲には関係なく, 舌運動評価に扔いて「やや不良」に属する症例である (図 14).

今井ら ${ }^{50}$ は本装置の効果は構音の改善だけではなく 嚥下機能, 心理的側面にも及んでいるので, 適応はこ れらの機能を含めて広い意味で考えたほうがよいと述 べている. また, 別の論文で今井ら ${ }^{51)}$ は, 本装置装着後 に構音訓練を行ったところ併用効果が認められたと報 告し, 発音補助装置を装着して,さらに構音訓練を行 うとより効果的であるということを強調している。 


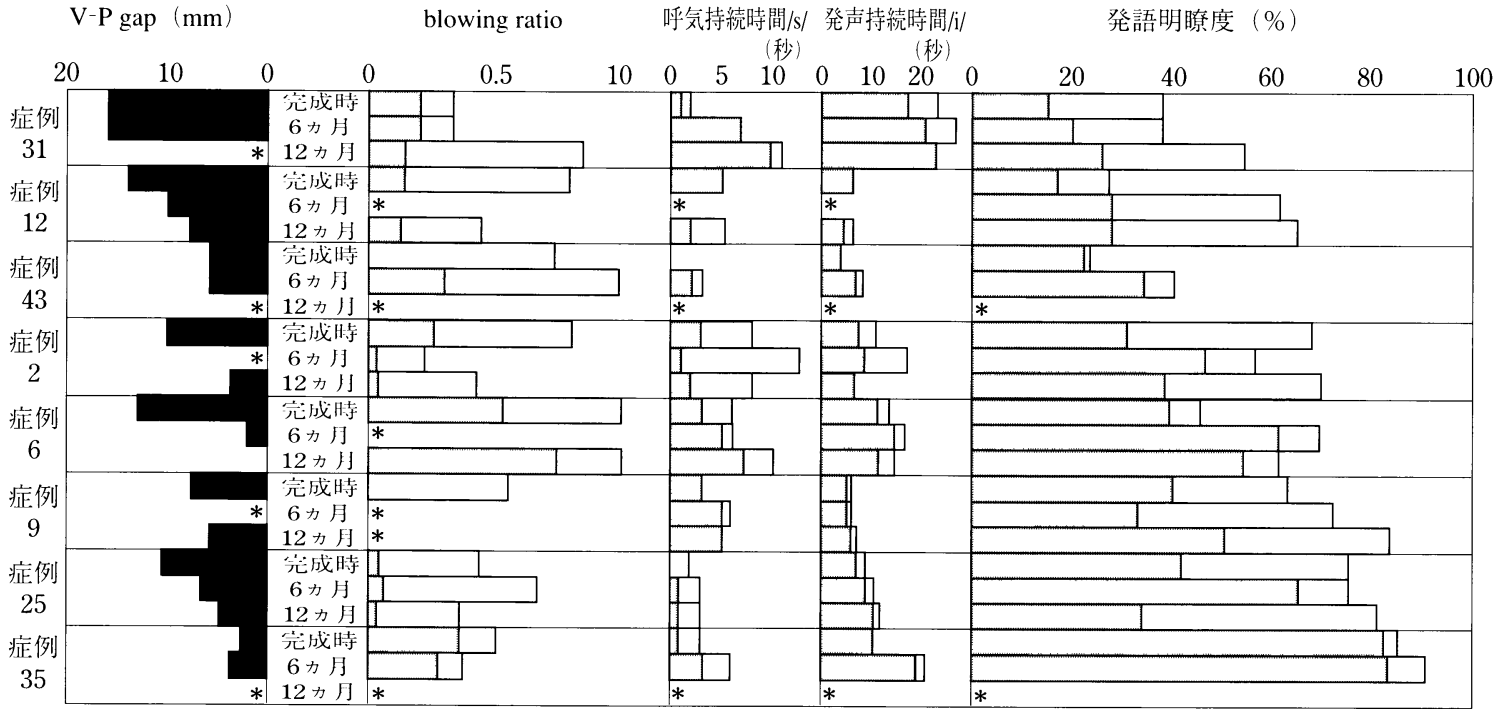

$\square$ PLP 装着時 $\square$ PLP 非装着時 *データなし

図 12 後天性運動障害性構音障害症例への軟口蓋挙上装置装着後の経時的変化（山下ら ${ }^{36)}, 1990$ )

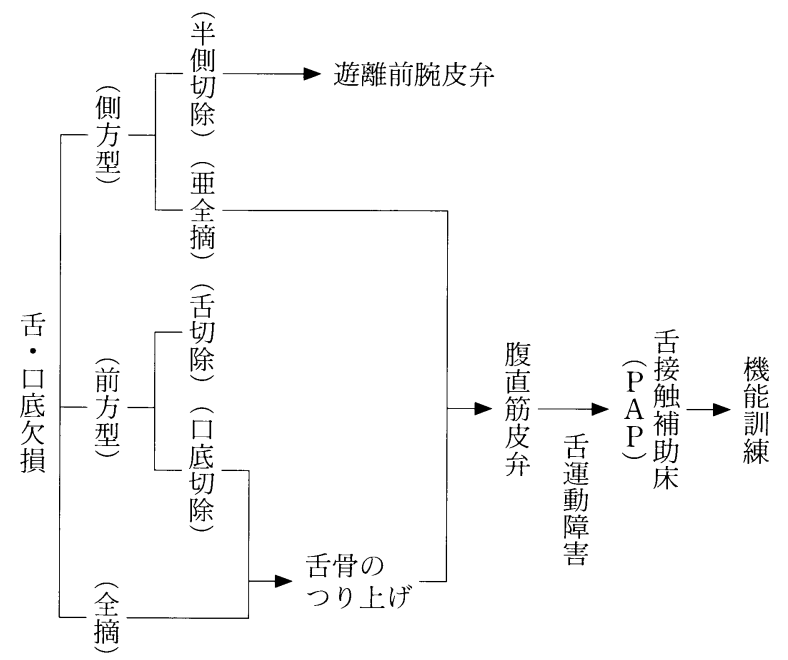

図 13 舌・口底切除症例に対する言語治療の方針 (道ら $\left.{ }^{3)}, 2000\right)$

\section{おわりに}

最初に述べたように言語障害の治療法には外科的治 療，機能訓練のほかに補綴的治療がある。そのなかで, 補経的治療に関する記載は少なく，いまだ十分に普及 しているとは思われない，本稿では補綴的治療の適応 と効果について述べたが，それが常に最適であるとい うことではない.これらの3つの治療法はそれぞれに 利点，欠点があるので，適応症例に応じて選択し，ま
た，必要に応じて併用することが肝要である．特に， 外科的治療が適応し難い条件のある患者，あるいは外 科的治療をすでに行って言語障害が残存している患者 では補経的治療の適応を第一選択に考えて治療方針を 立てるべきである。

補経物の製作にあたつては歯科医師の技術が必須で あるが，発音補助装置を適合させるためには音声学の 知識や聴覚判定が重要であり，言語聴覚士との連携が 不可欠である。さらに, 発音補助装置は言語訓練の効 


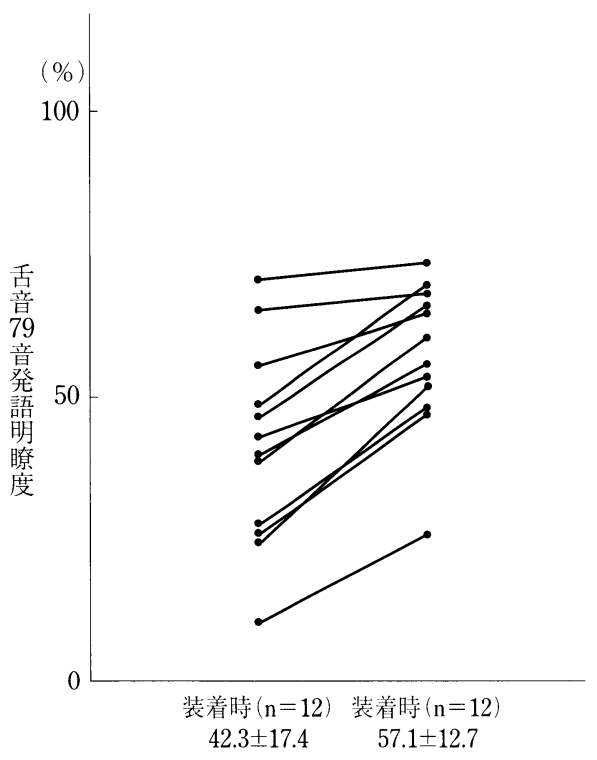

図 14 舌・口底切除症例に対する舌接触補 助床装着前後の舌音 79 音の発語明 瞭度の推移（齋藤ら ${ }^{49}$, 1991）

率を高める働きがあると同時に，言語訓練を併用する ことにより装置の適合性が高まるという側面があるの で補経的治療においては言語聴覚士の果たす役割が大 きいことを強調したい.

\section{文献}

1）道 健一：口腔疾患による言語障害の診断と治 療。口科誌，35：1035-1076，1986.

2）道 健一：口腔機能障害の診断と治療に関する研 究一口腔機能の評価法の開発一. 昭歯誌, $18: 1$ 37, 1998.

3）道 健一, 今井智子, 大野康亮, 他：歯 - 口腔 顎・顔面の機能障害の治療．言語聴覚士ための臨 床歯科医学・腔外科学 (道 健一編), 医歯薬出 版, 東京, 175-249 頁, 2000 .

4）小林敏雄: 発音補助装置（スピーチ・エイド）装着 による口蓋裂患者の言語改善に関する臨床的研 究. 口病誌, $39 ： 383-431,1972$.

5）大橋 靖：鼻咽腔閉鎖不全に対するスピーチ・エ イドの効用. 日口外誌， $30 ： 564-570,1984$.

6）塩入重彰, 大畑 昇, 石島 勉, 他：第 31 回用語 検討委員会報告. 顎顔面補経, $23 ： 139-141,2000$.

7) Leonard, R.J. and Gillies, R.E. : Effects of a prosthetic tongue on vowel formants and isovowel lines in a patient with total glossectomy.
J Speech Hear Disord, 47：25-30, 1982.

8）谷口 尚：Obturator Prosthesis に関する研究の 現状。口病誌，67：11-22，2000。

9) Matsui, Y., Ohno, K., Shirota, T., et al : Speech function following maxillectomy reconstructed by rectus abdominis myocutaneous flap. J Craniomaxillofac Surg, $23: 160-164,1995$.

10）大澤毅晃：上顎・軟口蓋切除症例の言語障害とそ の治療に関する研究。口科誌, 39：405-424, 1990.

11) Yoshida, H., Michi, K. and Ohsawa, T. : Prosthetic treatment for speech disorders due to surgically acquired maxillary defects. J Oral Rehabil, $17: 565-571,1990$.

12）高橋泰伸：上䫈欠損補綴患者の発音機能. 大阪大 歯誌，31：97-117， 1986.

13）大野康亮, 松井義郎, 今井智子, 他：インプラン 卜義歯による咀嚼ならびに構音機能の再建. 頭頝 部腫場, $21 ： 501-506,1995$.

14）山下夕香里, 鈴木規子, 今井智子, 他：口蓋裂術 後の鼻咽腔閉鎖機能不全に対する補経的発音補助 装置の長期治療成績. 日口蓋誌，23：243-256, 1998.

15）吉田 広, 道 健一, 朽名正也, 他：スピーチ・エ イド（補経的発音補助装置）による鼻咽腔閉鎖機 能不全症の治療成績. 昭和医学会雑誌, 39：507517, 1979 .

16）今井智子, 吉田 広, 山下夕香里, 他: 先天性鼻 咽腔閉鎖機能不全症の治療成績について. 日口蓋 誌，13：281-295， 1988.

17）舘村 卓, 高英 保, 原 久永, 他: スピーチエ イド装着による鼻咽腔閉鎖機能の予備能の形成. 音声言語医学, 38：337-343， 1997.

18）舘村 卓, 高英 保, 原 久永, 他：スピーチエ イド装着にともなう発音時口蓋帆挙筋活動の変 化. 日口蓋誌，22：24-31，1997.

19）吉田 広，道 健一，鈴木規子，他：軟口蓋 造影 $\mathrm{X}$ 線規格写真による先天性鼻咽腔閉鎖不全症の分 類について。 日口外誌，28：813-828，1982.

20）今井智子, 鈴木規子, 森紀美江, 他：染色体 22q11 の欠失を示した先天性鼻咽腔閉鎖不全症症例につ いて. 日口蓋誌，23：287-299， 1998.

21）道 健一：口腔・中咽頭癌手術の機能評価. 口腔 腫瘍, 13：59-73，2001.

22) Harii, K., Asato, H., Nakatsuka, T., et al: Reconstructive plastic surgery in cancer treatment : surgery for quality of life. Int J Clin 
Oncol, 4:193-201, 1999.

23) Michiwaki, Y., Schmelzeisen, R., Hacki, T., et al : Functional effects of a free jejunum flap used for reconstruction in the oropharyngeal region. J Craniomaxillofac Surg, 21 : 153-156, 1993.

24）秋月弘道, 大野康亮, 根本敏之, 他：口腔外科領 域における遊離組織移植術後の口腔機能一アンケ ートによる調査一. 日口外誌, 41：411-413, 1995.

25）道 健一, 今井智子, 大野康亮, 他: 言語機能の 障害. 言語聴覚士ための臨床歯科医学・腔外科 学 (道 健一編), 医歯薬出版, 東京, 126-149 頁, 2000 .

26）鈴木規子, 藤田幸弘, 斎藤裕人, 他：中咽頭切除 症例に対するリハビリテーションー軟口蓋部を肥 厚させた舌接触補助床適用の試み一.頭頝部腫瘍, 27 :212-218, 2001.

27）大野康亮, 中村 篤, 山下夕香里, 他：軟口蓋お よび中咽頭側壁部欠損症例への遊離前腕皮弁によ る即時再建と補綴的発音補助装置の併用. 口科誌, 41：401-413, 1992.

28）今井智子, 大野康亮, 山下夕香里, 他：遊離組織 移植による中咽頭再建症例への発音補助装置の応 用一装着前後の鼻咽腔閉鎖機能および構音機能の 変化一。 日口外誌，41：45-51，1995.

29）藤田幸弘, 鈴木規子, 道 健一：中咽頭切除症例 に対する補経的発音補助装置の治療効果に関する 検討。口科誌，51：116-131，2002.

30) Yoshida, H., Michi, K., Yamashita, Y., et al : A comparison of surgical and prosthetic treatment of speech disorders attributable to surgically aquired soft palate defect. J Oral Maxillofac Surg, $51: 361-365,1993$.

31) Yorkston, K.M., Beukelman, D.R., Strand, E.A., et al : Velopharyngeal function. Management of Motor Speech Disorders in Children and Adults, 2nd ed., Pro-ed, Austin, pp. 359-400, 1999.

32）道 健一, 山下夕香里, 今井智子, 他：後天性運 動障害性構音障害に対する軟口蓋挙上装置 (Palatal lift prosthesis）の使用経験. 音声言語医学, $29: 239-255,1988$.

33) Noll, J.D. : Remediation of impaired resonance among patients with neuropathologies of speech. Speech Language and Hearing : Vol. 3: Pathologies of Speech and Language (edited by Lass, N., et al), Saunders, Philadelphia, pp.
556-571, 1982.

34) Hardy, J., Rembolt, R., Schweiger, J., et al: Surgical management of palatal paresis and speech problems in cerebral palsy : A preliminary report. J Speech Hear Disord, 26 : 320-325, 1961.

35) Rosenbek, J.C. and LaPointe, L.L. : The dysarthrias : Description, diagnosis, and treatment. Clinical Management of Neurogenic Communication Disorders (edited by Johns, D.), Little Brown, Boston, pp. 97-152, 1985.

36）山下夕香里，今井智子：鼻咽腔閉鎖不全を伴った 後天性運動障害性構音障害患者における軟口蓋挙 上装置の効果. 聴能言語研究, 7：44-54, 1990.

37）道 健一, 今井智子, 大野康亮, 他：言語機能の 障害. 言語聴覚士ための臨床歯科医学・ロ腔外科 学 (道 健一編), 医歯薬出版, 東京, 126-149 頁, 2000 .

38）今井智子, 道 健一, 山下夕香里, 他：舌・口底 切除後の語音発語明瞭度一切除範囲および手術法 との関連について一. 日口外誌, $34: 1567-1583$, 1988.

39) Michiwaki, Y., Ohno, K., Imai, S., et al : Functional effects of intraoral reconstruction with a free radial forearm flap. J Craniomaxillofac Sur, $18: 164-168,1990$.

40）道脇幸博, 齋藤健一, 大野康亮, 他: 舌癌再建症 例の術後の構音機能に関する多施設共同研究. 腔腫瘍，9：269-275，1997.

41）道脇幸博, 齋藤健一, 大野康亮, 他：口底癌再建 症例の術後の構音機能に関する多施設共同研究. 口腔腫瘍, 10：63-70, 1998.

42) Michiwaki, Y., Schmelzeisen, R., Hacki, T., et al: Articulatory function in glossectomized patients with immediate reconstruction using a free jejunum flap. J Craniomaxillofac Surg, $20: 203-210,1992$.

43) Michi, K., Imai, S., Yamashita, Y., et al: Improvement of speech intelligibility by a secondary operation to mobilize the tongue after glossectomy. J Craniomaxillofac Surg, $17: 162$ $-166,1989$.

44) Imai, S., Michi, K. : Articulatory function after resection of the tongue and floor of the mouth: palatometric and perceptual evalution. J Speech Hear Res, 35 : 68-78, 1992. 
45）今井智子, 道 健一, 山下夕香里, 他: 舌・口底切 除後前腕皮弁再建例のエレクトロパラトグラム所 見について。音声言語医学, 32：318-332，1991.

46）秋月弘道, 吉田 広, 森紀美江, 他：超音波診断 装置による舌切除患者の舌運動の観察. 日口外誌, 37：24-29, 1991.

47）斎藤裕人，鈴木規子，藤田幸弘，他：MRIによる 舌接触補助床装着前後の発音時 3 次元声道形状の 観察. 舌 - 口底切除症例への適用. 顎顔面補経, $23: 122,2000$.

48）斎藤裕人, 赤木正人, 鈴木規子, 他：舌・口底切除 症例における舌接触補助床適用前後の音響特性の 変化. 日本音響学会平成 10 年度春季研究発表会講 演論文集 1,261 頁, 1988.
49）齋藤健一, 道 健一, 松田千春, 他: 舌 - 口底切 除患者に対する舌接触床装着前後の言語所見. 頭 斋部腫瘍, $17: 5-11,1991$.

50）今井智子, 山下夕香里：舌・口底切除症例に対す る舌接触補助床の有効性: 舌接触部位別および構 音様式別明瞭度の変化について. 聴能言語学研究, 9:1-9, 1992.

51）今井智子, 佐藤真由美, 道 健一：舌切除患者の 構音訓練の経過一舌接触補助床装着例について 一. 音声言語医学, $36: 218-227,1995$.

別刷請求先： $\overline{1}$ 145-8515 東京都大田区北千束 2-1-1 昭和大学歯学部第一口腔外科 道 健一 